\title{
Bartłomiej Chludziński
}

Uniwersytet Mikołaja Kopernika, Toruń

\section{Prawo do sądu a reforma postępowania sądowoadministracyjnego}

DOI: http://dx.doi.org/10.12775/SIT.2015.017

\section{Przyczyn reformy postępowania sądowoadministracyjnego}

Reforma pionu sądownictwa administracyjnego ${ }^{1}$ podyktowana była wieloma różnymi czynnikami. Trudno o ich jednoznaczną i wyczerpującą klasyfikację. Fundamentalne założenia wyjściowe reformy sądownictwa administracyjnego wskazał R. Hauser, zaliczając do

${ }^{1}$ W warstwie normatywnej reforma przyjęła postać trzech aktów prawnych: ustawy z dnia 25 lipca 2002 r. Prawo o ustroju sądów administracyjnych (Dz.U. Nr 153, poz. 1269 ze. zm.; dalej: p.u.s.a.), ustawy z dnia 30 sierpnia 2002 r. Prawo o postępowaniu przed sądami administracyjnymi (t.j.: Dz.U. z 2012 r., poz. 270 ze zm.; dalej: p.p.s.a) oraz ustawy z dnia 30 sierpnia 2002 r. Przepisy wprowadzające ustawę Prawo o ustroju sądów administracyjnych i ustawę Prawo o postępowaniu przed sądami administracyjnymi (Dz.U. Nr 153, poz. 1271 ze. zm.). Ustawa $z$ dnia 30 sierpnia 2002 r. Prawo o postępowaniu przed sądami administracyjnymi oraz ustawa $z$ dnia 25 lipca 2002 r. Prawo o ustroju sądów administracyjnych weszły w życie $z$ dniem 1 stycznia 2004 r. Natomiast ustawa $z$ dnia 30 sierpnia 2002 r. Przepisy wprowadzające ustawę Prawo o ustroju sądów administracyjnych i ustawa Prawo o postępowaniu przed sądami administracyjnymi zgodnie $z$ jej art. 106 weszła w życie $z$ dniem 1 stycznia 2004 r., z wyjątkiem przepisów art. 8 pkt 1 i 2, art. 10 pkt 2 i 3, art. 84 pkt 1 , art. $86 \S 1$, art. $87 \S 2$, art. 88 , art. $90 \S 1$, art. 91 i art. 92 , które weszły w życie po upływie 14 dni od dnia ogłoszenia. 
nich przede wszystkim: realizację konstytucyjnej zasady demokratycznego państwa prawa; realizację standardów przyjętych w doktrynie i orzecznictwie państw Europy Zachodniej, wynikających $z$ norm prawa międzynarodowego; zapewnienie obywatelom i innym podmiotom ochrony przed naruszeniami prawa przez organy administracji publicznej; zapewnienie organom administracji publicznej pomocy ze strony wymiaru sprawiedliwości w zakresie prawidłowego i jednolitego stosowania prawa; zapewnienie wysokiego poziomu orzecznictwa sadów administracyjnych; właściwe usytuowanie sądownictwa administracyjnego w strukturze wymiaru sprawiedliwości ${ }^{2}$.

Normatywnym źródłem reformy była Konstytucja Rzeczypospolitej Polskiej z dnia 2 kwietnia 1997 r. ${ }^{3} \mathrm{~W}$ warstwie prawnej reforma postępowania sądowoadministracyjnego podyktowana była zatem koniecznością realizacji postanowień Konstytucji RP, zawierających przepisy przesądzające o systemie sądownictwa administracyjnego. $Z$ przepisów ustawy zasadniczej wynika wprost, że: sądy administracyjne sprawują wymiar sprawiedliwości jako wyodrębniona część władzy sądowniczej (art. 10, art. 175 ust. 1, art. 177, art. 183 ust. 1, art. 184); postępowanie sądowe, w tym przed sądami administracyjnymi, jest dwuinstancyjne (art. 176 ust. 1); odrębny pion dwuinstancyjnego sądownictwa administracyjnego tworzą Naczelny Sąd Administracyjny i wojewódzkie sądy administracyjne (art. 184); sądy administracyjne powołane są do kontroli działalności administracji publicznej, w tym do orzekania zgodności z ustawami uchwał organów samorządu terytorialnego i aktów normatywnych terenowej administracji rządowej (art. 184); sądy administracyjne rozstrzygają spory kompetencyjne między organami samorządu terytorialnego i administracji rządowej (art. 166 ust. 3); ochroną sądową objęta jest samodzielność jednostek samorządu terytorialnego (art. 165 ust. 2). Przepis art. 236 ust. 2 Konstytucji wskazywał przy tym, że ustawy wprowadzające w życie art. 176

${ }^{2}$ R. Hauser, Prawo do sądu - referat, w: Konferencja naukowa: Konstytucja $R P w$ praktyce, Warszawa 1999, s. 200.

${ }^{3}$ Dz.U. Nr 78, poz. 483 ze. zm. 
ust. $1 \mathrm{w}$ zakresie dotyczącym postępowania przed sądami administracyjnymi zostaną uchwalone przed upływem 5 lat od dnia wejścia w życie Konstytucji. Należy przy tym podkreślić, że procesowa część reformy miała przede wszystkim na celu zrealizowanie zasady dwuinstancyjnego postępowania administracyjnego oraz kompleksowe uregulowanie postępowania w sprawach sądowoadministracyjnych $^{4}$ bez konieczności odsyłania do Kodeksu postępowania administracyjnego ${ }^{5}$ i Kodeksu postępowania cywilnego ${ }^{6}$, tak jak to czyniła ustawa o Naczelnym Sądzie Administracyjnym ${ }^{7}$. Dążono przy tym do zapewnienia zgodności rozwiązań krajowych $z$ aktami międzynarodowymi - wiążących Polskę umów międzynarodowych ${ }^{8}$ oraz rekomendacji Komitetu Rady Europy ${ }^{9}$. W tej mierze jako jeden $z$ istotniejszych czynników warunkujących reformę manifestuje się potrzeba ochrony praw podmiotowych.

$Z$ tekstu uzasadnienia, skierowanego do prac sejmowych prezydenckiego projektu ustawy o postępowaniu przed sądami admi-

${ }^{4}$ Zob. E. Ochendowski, Postępowanie administracyjne ogólne, egzekucyjne i sądowoadministracyjne, Toruń 2012, s. 333.

${ }^{5}$ Ustawa $z$ dnia 14 czerwca $1960 \mathrm{r}$. Kodeks postępowania administracyjnego (t.j.: Dz.U. z 2013 r., poz. 267 ze zm.)

${ }^{6}$ Ustawa $z$ dnia 17 listopada 1964 r. Kodeks postępowania cywilnego (t.j.: Dz.U. z 2014 r., poz. 101 ze. zm.)

7 Ustawa z dnia 11 maja 1995 r. o Naczelnym Sądzie Administracyjnym (Dz.U. Nr 74, poz. 368 ze. zm.).

8 Międzynarodowy Pakt Praw Obywatelskich i Politycznych otwarty do podpisu w Nowym Jorku dnia 16 grudnia 1966 r., (Dz.U. z 1997 r. Nr. 38, poz. 167), Europejska Konwencja o Ochronie Praw Człowieka i Podstawowych Wolności otwarta do podpisu w Rzymie dnia 4 listopada 1950 r. (Dz.U. z 1993 r. Nr. 61, poz. 284, ze. zm.; dalej: Konwencja).

${ }^{9}$ Rekomendacjami tymi były m.in. rekomendacja Nr R (81) 7 z dnia 14 maja 1981 r. o środkach ułatwiających dostęp do wymiaru sprawiedliwości, rekomendacja Nr R (86) 12 z 16 września 1986 r. o środkach zapobiegających nadmiernemu obciążeniu sądów i ograniczających to obciążenie, rekomendacja Mr R (87) 16 z dnia 17 września 1987 o postępowaniach administracyjnych dotykających znaczną liczbę osób, rekomendacja Nr R (89) 8 z dnia 13 września 1989 r. o tymczasowej ochronie sądowej w sprawach administracyjnych czy rekomendacja Nr R (94) 12 z dnia 13 października 1994 r. o niezawisłości, skuteczności i roli sędziów. Teksty rekomendacji Komitetu rady Europy dostępne są pod adresem: wcd.coe.int 
nistracyjnymi ${ }^{10}$, wynika, że reformowana procedura sądowoadministracyjna realizowała zasady i obowiązki, których źródłem jest Konstytucja Rzeczypospolitej Polskiej, pozostawała pod wpływem postanowień umów międzynarodowych podpisanych przez Polskę i nawiązywała do rekomendacji Komitetu Rady Europy „tak aby przyszła ustawa zapewniała przede wszystkim ochronę szeroko rozumianych praw człowieka”. Wśród praw człowieka, ochronie których sprzyjać miała reforma sądowoadministracyjna, szczególne znaczenie przypisano konieczności zagwarantowania prawa wywodzonego z niezbywalnej godności człowieka. Prawa, które ,jest genetycznie i organicznie związane $z$ ideą demokratycznego państwa prawnego" ${ }^{11}$. Prawa do sądu ${ }^{12}$.

W postulat ten wpisuje się funkcjonalna część reformy, w której manifestuje się dążenie do wyznaczenia wysokiego standardu ochrony praw stron postępowania sądowoadministracyjnego. Towarzyszy temu konieczność sprawnego i szybkiego rozpoznawania spraw. Realizacja tego postulatu miała dokonać się poprzez uproszczenie procedury oraz przebiegu postępowania przed sądami administracyjnymi. Jednocześnie nowe rozwiązania w zakresie

${ }^{10}$ Prace nad projektami ustaw reformujących pion sądownictwa administracyjnego podjęto w działającym pod auspicjami Instytutu Spraw Publicznych zespole prof. dr hab. Dariusza Kijowskiego oraz w kierowanym przez prof. dr hab. Romana Hausera zespole Naczelnego Sądu Administracyjnego. Projekty przygotowane w zespole NSA $z$ inicjatywy Prezydenta RP zostały skierowane do Sejmu, efektem czego było uchwalenie p.u.s.a. i p.p.s.a.

${ }_{11}$ Zob. Z. Czeszejko-Sochacki, Prawo do sądu w świetle Konstytucji Rzeczypospolitej Polskiej (ogólna charakterystyka), „Państwo i Prawo” 1997, z. 11-12, s. 87; Z. Czeszejko-Sochacki, Konstytucyjna zasada prawa do sądu, „Państwo i Prawo” 1992, z. 10, s. 23. Zob. też wyrok ETPC w sprawie Wassink v. Holandia z dnia 27 września 1990 r., A. 185-A, § 38 oraz wyrok TK z dnia 7 stycznia 1992 r., K 8/91, OTK $1992 \mathrm{Nr}$ 1, poz. 5, a także wyrok TK z dnia 8 kwietnia 1997 r., K 14/96, OTK 1997 Nr 2, poz. 16.

12 Prawo do sądu jest nie tylko podmiotowym prawem jednostki, ale również jedną z naczelnych konstytucyjnych zasad sądowego wymiaru sprawiedliwości; jako takie wymaga, aby konkretyzujące je normy formułowane były zgodnie $z$ tą zasadą. W. Piątek, Podstawy skargi kasacyjnej $w$ postępowaniu sądowoadministracyjnym, Warszawa 2011, s. 98; A. Łazarska, Rzetelny proces cywilny, Warszawa 2012, s. 58. 
sądownictwa administracyjnego miały przełożyć się na ogólną poprawę działania organów administracji publicznej ${ }^{13}$.

\section{Pojęcie i elementy prawa do sądu}

Gwarancja prawa do sądu w demokratycznym państwie prawnym potwierdza personalistyczny charakter koncepcji praw człowieka. Koncepcji, zgodnie $z$ którą człowiek to podmiot prawnie i społecznie samodzielny ${ }^{14}$. W demokratycznym porządku prawnym ta samodzielna jednostka może oczekiwać od państwa ochrony sądowej. Koresponduje $z$ tym potrzeba poczucia sprawiedliwości pojmowana tu nie jako zapewnienie korzystającej $z$ tej ochrony jednostce pożądanego przez nią wyniku sprawy, ale obowiązek zajęcia się tą sprawą przez właściwy sąd i pomoc w uzyskaniu obiektywnego rozstrzygnięcia na przykład w przypadku sporu ${ }^{15}$.

Tak pojmowane prawo do sądu gwarantowane jest w międzynarodowych i krajowych aktach normatywnych. Niektóre $z$ nich brano pod uwagę $\mathrm{w}$ trakcie prac nad reformą sądownictwa administracyjnego.

Wskazuje się ${ }^{16}$, że umowami międzynarodowymi, które wywarły wpływ na kierunek reform polskiego sądownictwa administracyj-

${ }^{13}$ Zob. T. Woś, Condiciones necessariae dwuinstancyjnego sadownictwa administracyjnego, w: Dziedzictwo prawne XX wieku. Księga pamiątkowa $\mathrm{z}$ okazji 150-lecia TBSP UJ, Kraków 2001, s. 463-476; T. Woś, Reforma sądownictwa administracyjnego - projekty dalekie od ideału, „Państwo i Prawo” 2001, nr 7, s. 31-34; M. B. Wilbrandt-Gotowicz, Skarga kasacyjna w postępowaniu sądowoadministracyjnym, Toruń 2005, s. 16-17.

${ }^{14}$ Zob. Z. Kędzia, Prawa, wolności i obowiązki człowieka i obywatela w nowej polskiej Konstytucji, Poznań 1990, s. 15-16.

${ }^{15}$ Na temat prawa do ochrony sądowej szerzej zob. H. Mądrzak, Prawo do sądu jako gwarancja ochrony praw człowieka, w: Podstawowe prawa jednostki $i$ ich sądowa ochrona, red. L. Wiśniewski, Warszawa 1997. Zob. też wyrok Sądu Najwyższego z dnia 16 września 2009 r., I PK 59/09, dostępny w bazie orzeczeń SN pod adresem http://www.sn.pl.

${ }^{16}$ M. Jaśkowska, M. Masternak, E. Ochendowski, Postępowanie sądowoadministracyjne, Warszawa 2005, s. 27; T. Woś, H. Knysiak-Molczyk, M. Romańska, Postępowanie sądowoadministracyjne, Warszawa 2004, s. 17; uzasadnienie projektu p.p.s.a. opublikowane pod wskazanym wyżej adresem, s. 68. 
nego były Konwencja o Ochronie Praw Człowieka i Podstawowych Wolności z 4 listopada 1950 r. ${ }^{17}$ oraz Międzynarodowy Pakt Praw Obywatelskich i Politycznych z 19 grudnia 1996 r. ${ }^{18}$ Oba akty zawierają regulacje stanowiące gwarancje „prawa do sądu”.

W przypadku Międzynarodowego Paktu Praw Obywatelskich i Politycznych jest to art. 14 ust. 1, zgodnie z którym „każdy ma prawo do sprawiedliwego i publicznego rozpatrzenia sprawy przez właściwy, niezależny i bezstronny sąd, ustanowiony przez ustawę, przy orzekaniu co do zasadności oskarżenia przeciw niemu w sprawach karnych bądź co do jego praw i obowiązków w sprawach cywilnych". Natomiast w Konwencji o Ochronie Praw Człowieka i Podstawowych Wolności, prawo do sądu zostało wyrażone w art. 6 ust. 1 Konwencji, który między innymi stanowi, że „każdy ma prawo do sprawiedliwego i publicznego rozpatrzenia jego sprawy w rozsądnym terminie przez niezawisły i bezstronny sąd ustanowiony ustawą przy rozstrzyganiu o jego prawach i obowiązkach o charakterze cywilnym albo o zasadności każdego oskarżenia w wytoczonej przeciwko niemu sprawie karnej”19.

17 Dz.U. z 1993 r. Nr 61, poz. 284.

18 Dz.U. z 1977 r. Nr 38, poz. 167 zał.

19 Należy odnotować, że „prawo do sądu” zostało ujęte wśród praw i zasad, które składają się na treść Powszechnej Deklaracji Praw Człowieka (dalej: PDPC) uchwalonej przez Zgromadzenie Ogólne ONZ w dniu 10 grudnia 1948 r. w Paryżu. W art. 10 PDPC ustalono, że „każdy człowiek ma na warunkach całkowitej równości prawo, aby przy rozstrzyganiu o jego prawach i zobowiązaniach lub o zasadności wysuwanego przeciw niemu oskarżenia o popełnienie przestępstwa być słuchanym sprawiedliwie i publicznie przez niezależny i bezstronny sąd". Wyznaczony w ten sposób standard został następnie odzwierciedlony w uchwalonym na bazie Deklaracji Międzynarodowym Pakcie Praw Obywatelskich i Politycznych. Europejska Konwencja o Ochronie Praw Człowieka i Podstawowych Wolności w wyraźny sposób nawiązuje do postanowień powyższych aktów z tą ważną różnicą, iż Konwencja nakazuje rozpatrywać sprawy toczące się przed organami sądowym w „rozsądnym terminie”. K. Kowalik-Bańczyk, Prawo do obrony $w$ unijnych postępowaniach antymonopolowych $w$ kierunku unifikacji standardów proceduralnych $w$ Unii Europejskiej, Warszawa 2012, s. 85-86. Natomiast w prawie Unii Europejskiej, ,prawo do sądu” zostało zagwarantowane w art. 47 Karty Praw Podstawowych Unii Europejskiej (Dz. Urz. UE C 303 z dnia 14 grudnia 2007, s. 1), który m.in. stanowi, że „każdy ma prawo do sprawie- 
Uchwalony w wyniku konferencji Organizacji Narodów Zjednoczonych Międzynarodowy Pakt Praw Obywatelskich i Politycznych jest elementem szeroko rozumianego międzynarodowego systemu ochrony praw człowieka. Natomiast stworzone przez Radę Europy regulacje Konwencji trwale wpisane są w stricte europejski dorobek na tym polu. W związku $\mathrm{z}$ tym „w wymiarze europejskim podstawowym przepisem, do którego odwołują się organy stosujące prawo, jest art. 6 ust. 1 Konwencji” ${ }^{20}$. Doprecyzowaniu tej regulacji, jak również usystematyzowaniu wypracowanych na jej podstawie standardów służą rekomendacje Komitetu Ministrów Rady Europy.

Jednocześnie w zakresie odpowiedniej wykładni pojęcia „prawa do sądu" dostrzec trzeba ogromny wkład Europejskiego Trybunału Praw Człowieka, który w swych licznych wyrokach odnosił się do tego zagadnienia.

Dokonując wstępnej delimitacji materiału źródłowego, problematykę prawa do sądu na gruncie prawa międzynarodowego chciałbym ukazać w odniesieniu do aktów prawa europejskiego. Wobec tego kwestia ta zostanie ukazana w świetle art. 6 ust. 1 Konwencji, rekomendacji o sądowej kontroli aktów administracyjnych oraz orzecznictwa Europejskiego Trybunału Praw Człowieka. Natomiast wśród źródeł prawa krajowego pierwszorzędnym polem analizy „prawa do sądu” są regulacje Konstytucji RP.

Przepisem stanowiącym konstytucyjną gwarancję prawa do sądu jest art. 45 ust. 1. Prawo do sądu w ustawie zasadniczej zostało sformułowane w następujący sposób: „każdy ma prawo do sprawiedliwego i jawnego rozpatrzenia sprawy bez nieuzasadnionej zwłoki przez właściwy, niezależny, bezstronny i niezawisły sąd”. Publiczne prawo podmiotowe wyrażone w art. 45 ust. 1 jest kształtowane również przez inne przepisy Konstytucji. Są to przepisy: art. 77 ust. 2, na mocy którego ustawa nie może nikomu zamykać drogi sądowej dochodzenia naruszonych wolności lub praw (przepis ten

dliwego i jawnego rozpatrzenia jego sprawy w rozsądnym terminie przez niezawisły i bezstronny sąd ustanowiony uprzednio na mocy ustawy".

${ }^{20}$ K. Kowalik-Bańczyk, op. cit., s. 86. 
modyfikuje ograniczenia określone w art. 31 ust. 3); art. 78 i 176, które każdą ze stron uprawniają do zaskarżenia orzeczeń i decyzji wydanych w pierwszej instancji i dochodzenia praw w co najmniej dwuinstancyjnym postępowaniu sądowym; art. 173 stanowiący, iż sądy i Trybunały są władzą odrębną oraz niezależną od innych władz; art. 175 ust. 1 i art. 177 wskazujące na wyłączną właściwość sądów w zakresie wymiaru sprawiedliwości oraz art. 178 ust. 1 zapewniający sędziom niezawisłość $\mathbf{c}^{21}$. Jednak $z$ uwagi na zasadniczy wymiar powołanej regulacji i jej bezpośrednie odniesienie do rozważanej kwestii, prawo do sądu w ujęciu konstytucyjnym przedstawione zostanie przez pryzmat art. 45 ust. 1 Konstytucji.

W oparciu o zacytowane wyżej regulacje konwencyjne i konstytucyjne w nauce prawa dokonano głębokiej analizy pojęcia „prawa do sądu”. Doktryna zna przez to liczne koncepcje zmierzające do ustalenia istoty tego zagadnienia ${ }^{22}$. Akcentując, że prawo do sądu może być prawidłowo realizowane jedynie w warunkach rzetelnego procesu, wskazuje się, że ,jest to prawo, które służy ochronie pozostałych praw i wolności” ${ }^{23}$ i jest „kluczem, który otwiera drogę do

${ }^{21}$ Zob. A. Wasilewski, Sądowa kontrola administracji a problem prawa do sądu, w: Księga pamiatkowa prof. E. Ochendowskiego, Toruń 1999, s. 343 i n.

22 A. Michalska, Prawa człowieka $w$ systemie norm międzynarodowych, Warszawa-Poznań 1982, s. 152; L. Garlicki, Prawo do sądu, w: Prawa człowieka. Model prawny, red. R. Wieruszewski, Wrocław 1991, s. 537; M. P. Wędrychowski, Prawo do „uczciwej rozprawy” w Europejskiej Konwencji Praw Człowieka, „Przegląd Sądowy” 1991, nr 5-6, s. 62 i nast.; L. Wiśniewski, Podstawowe prawa jednostki i ich sądowa ochrona, Warszawa 1997; Tuleja P., Prawo sędziowskie $z$ perspektywy konstytucyjnej, w: Konstytucja i sądowe gwarancje jej ochrony. Księga jubileuszowa Profesora Pawła Sarneckiego, red. K. Świerk-Bożek, Kraków 2004; M. Zubik, Sprawowanie wymiaru sprawiedliwości w świetle Konstytucji i orzecznictwa Trybunału Konstytucyjnego, „Przegląd Sejmowy” 2005, nr 3; P. Pogonowski, Realizacja prawa do sadu w postępowaniu cywilnym, Warszawa 2005; A. Góra-Błaszczykowska, „Rzetelne postępowanie przed sądem” według Trybunału Konstytucyjnego, w: Jus et Remedium. Księga jubileuszowa Profesora Mieczysława Sawczuka, red. A. Jakubecki, J. A. Strzępka, Warszawa 2010; Z. Kmieciak, Postępowanie administracyjne $i$ sadowoadministracyjne a prawo europejskie, Warszawa 2010.

${ }^{23}$ Zob. A. Wróbel, Prawo do sądu - tezy referatu, w: Konstytucja RP w praktyce. Konferencja naukowa, Warszawa 1999, s. 212. 
urzeczywistnienia praw podmiotowych"24. Przegląd definicji rzetelnego procesu pozwala uznać, że jest to „zasada sądowego wymiaru sprawiedliwości, ale także prawo podmiotowe, gwarantujące każdemu ochronę jego praw realizowaną przez wytoczenie powództwa i uzyskanie kwalifikowanej ochrony prawnej przed sądem. Korelatem tego prawa jest obowiązek bezstronnego, niezawisłego, jawnego i sprawiedliwego rozpatrzenia sprawy przez organy państwa bez nieuzasadnionej zwłoki”25.

Lokując rozważania na ten temat $\mathrm{w}$ ramach postępowania sądowoadministracyjnego, najczęściej za A. Zielińskim definiuje się to pojęcie jako „prawo każdej jednostki ludzkiej do korzystania $z$ ochrony swych praw podmiotowych na drodze postępowania sądowego, w którym przestrzegane są odpowiednie gwarancje proceduralne"; prawo do sądu jest przy tym kategorią złożoną składającą się z następujących powiązanych ze sobą elementów: 1) gwarancji dostępu do sądu; 2) posiadania przez organ udzielający ochrony prawnej wszelkich cech sądu; 3) zapewnienia właściwego (sprawiedliwego, praworządnego, rzetelnego, uczciwego) przebiegu procesu; 4) szybkiego i skutecznego wykonywania orzeczeń sądowych $^{26}$. Podobny podział komponentów prawa do sądu zaproponowano w rekomendacji o sądowej kontroli aktów administracyjnych. Zgodnie $z$ rekomendacją na prawo do sądu składają się: 1) dostęp do sądu; 2) niezawisłość i bezstronność sądu; 3) rzetelność rozprawy; 4) efektywność kontroli sądowej ${ }^{27}$.

${ }^{24}$ A. Zieliński, Prawo do sądu i organizacja władzy sądowniczej, w: Księga XX-lecia Orzecznictwa Trybunału Konstytucyjnego, red. M. Zubik, Warszawa 2006, s. 493.

${ }^{25}$ Gruntownego przeglądu definicji prawa do rzetelnego procesu dokonała A. Łazarska w pracy Rzetelny proces cywilny. Należy jej również przypisać autorstwo zaprezentowanego ujęcia prawa do rzetelnego procesu. A. Łazarska, op. cit., s. 75 .

${ }^{26}$ Zob. A. Zieliński, Postępowanie przed NSA $w$ świetle „prawa do sprawiedliwego procesu sądowego”, „Państwo i Prawo” 1992, z. 7, s. 15, 17.

${ }^{27}$ Z. Kmieciak, op. cit., s. 111. W kontekście sądowej kontroli administracji autor ten wskazuje również na wyliczenie elementów sprawiedliwego postępowania sądowego znajdujące się w opracowaniu przygotowanym na zlecenie Europejskiego Komitet Współpracy Prawnej Rady Europy: Principles of Administrative Law Concerning the Relations Between Administrative Authorities and Private 
Ta teoretyczna uwaga i normatywne rozwiązania, które stanowią jej rozwinięcie, znajdują wyraz w orzecznictwie Trybunału Konstytucyjnego i sądów administracyjnych. W bogatym dorobku Trybunału Konstytucyjnego dotyczącym prawa do sądu wskazuje się, że na treść tego prawa podmiotowego składają się następujące elementy: 1) prawo dostępu do sądu, tj. prawo uruchomienia procedury przed sądem - organem o określonej charakterystyce (niezależnym, bezstronnym i niezawisłym); 2) prawo do odpowiedniego ukształtowania procedury sądowej, zgodnie $z$ wymogami sprawiedliwości i jawności; 3) prawo do wyroku sądowego, tj. prawo do uzyskania wiążącego rozstrzygnięcia danej sprawy przez sąd; 4) prawo do odpowiedniego ukształtowania ustroju i pozycji organów rozpoznających sprawy ${ }^{28}$. Podobne konstatacje odnajdziemy w wyrokach i postanowieniach sądów administracyjnych ${ }^{29}$.

Persons, Strasbourg 1996. W dokumencie tym jako elementy prawa do sądu wymienia się: niezawisłość i bezstronność powołanego na mocy ustawy sądu; sprawiedliwość i rozsądny czas postępowania; uczciwość i publiczny charakteru przeprowadzanej przed sądem rozprawy; efektywność udzielanej ochrony.

${ }^{28}$ Wyrok TK z dnia 27 maja 2008 r. SK 57/06, OTK 2008 Nr 4/A, poz. 63. Podobnie TK w wyrokach: wyrok z dnia 24 października 2007 r., sygn. SK 7/06, OTK 2007 Nr 9/A, poz. 108; z dnia 14 listopada 2007 r., sygn. SK 16/05, OTK $2007 \mathrm{Nr}$ 10/A, poz. 124; z dnia 18 lipca 2012, K 14/12, OTK $2012 \mathrm{Nr} 7 / \mathrm{A}$, poz. 82. Zob. też wyroki TK z dnia 9 czerwca 1998 r., K 28/97, OTK 1998 $\mathrm{Nr} 4$, poz. 50. Podobnie w wyroku TK z dnia 16 marca 1999 r., SK 19/98, OTK 1999 Nr 3, poz. 36; z dnia 19 lutego 2003 r., P 11/02, OTK-A 2003 Nr 2, poz. 12; z dnia 18 maja 2004 r., SK 38/03, OTK-A 2004 Nr 5, poz. 45; z dnia 7 września 2004 r., P 4/04, OTK 2004 Nr 8, poz. 81; z dnia 20 września 2006 r., SK 63/05, OTK-A 2006 Nr 8, poz. 108. Zob. A. Zieliński, Prawo do sądu a struktura sądownictwa, „Państwo i Prawo” 2003, z. 4, s. 20; R. Mikosz, M. Zirk-Sadowski, Granice prawa do sądu administracyjnego, „Zeszyty Naukowe Sądownictwa Administracyjnego" 2007, nr 3, s. 35-52.

${ }^{29}$ Zob. np. wyrok WSA w Poznaniu z dnia 4 kwietnia 2004 r., II/SA/Po 921/02, postanowienie NSA z dnia 19 marca 2008 r., II FZ 105/08; Postanowienie WSA w Warszawie $z$ dnia 11 stycznia 2010 r., III SO/Wa 2/10; wyrok NSA $z$ dnia 10 grudnia 2010 r., II FSK 1803/09. W powołanych wyrokach sądy administracyjne (odwołując się do dorobku orzeczniczego TK) wskazują, że na prawo do sądu wynikające $z$ art. 45 ust. 1 Konstytucji składają się cztery elementy: 1) prawo dostępu do sądu; 2) prawo do odpowiedniego ukształtowania procedury sądowej, zgodnie z wymogami sprawiedliwości i jawności; 3) prawo do wyroku sądowego; 4) prawo do odpowiedniego ukształtowania ustroju i pozycji 
Powyższe twierdzenia wskazują, że prawo do sądu może być rozpatrywane w kilku aspektach. Byłyby to zatem podmiotowy i przedmiotowy zakres tego uprawnienia oraz kwestia określonych cech, które charakteryzować powinny sąd i prowadzone przed nim postępowanie $^{30}$.

W dalszej części artykułu zreferowane zostaną kwestie związane $z$ podmiotowym i przedmiotowym aspektem prawa do sądu. W związku z tym w pierwszym rzędzie wyznaczyć należy zakres stosowania analizowanego uprawnienia, poczynając od zakreślenia kręgu podmiotów, do których adresowany jest art. 6 ust. 1 Konwencji i art. 45 ust. 1 Konstytucji.

\section{Zakres podmiotowy prawa do sądu}

Ustalenie zakresu podmiotowego sprowadza się do odkodowania znaczenia słowa „każdy”, którym Państwa Strony Konwencji oraz ustawodawca konstytucyjny posłużyli się w przepisach art. 6 ust. 1 Konwencji i art. 45 ust. 1 Konstytucji.

Odnosząc się do Konwencji, od początku jej obowiązywania bezspornym było, że prawo do sądu przysługuje wszystkim osobom fizycznym. Pewne wątpliwości budziło natomiast stosowanie regulacji Konwencji odnoszącej się do praw człowieka w stosunku do osób prawnych. Wątpliwości te usunięto w drodze wykładni sądowej i doktrynalnej na rzecz dostępu osób prawnych do sądu. Możli-

organów rozpoznających sprawy. Wszystkie powołane w tym rozdziale orzeczenia sądów administracyjnych są dostępne w bazie orzeczeń sądów administracyjnych (CBOSA) pod adresem: www.orzeczenia.nsa.gov.pl.

${ }^{30}$ Warto przy tym odnotować pogląd J. Zimmermanna, zgodnie z którym podmiotowa i przedmiotowa część prawa do sądu mają charakter kluczowy w tym sensie, że ich zachowanie wystarczy, aby prawo to nie doznało uszczerbku. Pozostałe elementy stanowią dla tego autora „obudowę” prawa do sądu i mimo iż przypisuje im ogromne znaczenie, to jednak stwierdza, że „ich potwierdzenie lub ograniczenie nie wpływają na samą zasadę, ale na zakres prawa do sądu i na możliwość jego rzeczywistej realizacji”. J. Zimmermann, Prawo do sądu $w$ prawie administracyjnym, „Ruch Prawniczy Ekonomiczny i Socjologiczny”, rok LXVIII (2006), z. 2, s. 312. 
wość powoływania się na art. 6 Konwencji przez osoby prawne wyinterpretowana została przede wszystkim $z$ określonego w art. 34 Konwencji prawa wnoszenia skargi indywidualnej przez „każdą osobę, organizację pozarządową lub grupę jednostek”. W ten sposób (zgodnie $z$ obowiązującym w tym zakresie standardem) pojęciu „każdy” nadano uniwersalny charakter, wpisując w zakres semantyczny tego pojęcia zarówno osoby fizyczne, jak i osoby prawne ${ }^{31}$.

Zakres podmiotowy konstytucyjnego prawa do sądu jest równie powszechny. Pojęciu „każdy” w tym przypadku odpowiada każda osoba fizyczna (bez względu na to, czy jest to obywatel RP, czy cudzoziemiec), każda osoba prawna i jednostka organizacyjna nieposiadająca osobowości prawnej ${ }^{32}$. W powoływanym już wyroku Trybunału Konstytucyjnego Trybunał ten stwierdził, że „każdy obywatel RP i każdy szeroko rozumiany podmiot w RP powinien mieć zapewnioną możność dochodzenia swych praw przed niezawisłym sądem. Prawo do sądu jest bowiem gwarancją ładu prawnego oraz przestrzegania prawa przez wszystkich"33.

Wobec powyższego można stwierdzić, że prawo do sądu przysługuje każdej osobie fizycznej, każdej osobie prawnej i każdej jednostce organizacyjnej nieposiadającej osobowości prawnej.

\section{Zakres przedmiotowy prawa do sądu}

Ustalenie zakresu przedmiotowego prawa do sądu wyznaczonego przepisami Konwencji i Konstytucji sprowadza się do zasadniczego

31 Zob. K. Kowalik-Bańczyk, op. cit., s. 297, a także wyrok ETPC w sprawie Dombo Beheer przeciwko Królestwu Niderlandów z dnia 27 października 1993 r., nr skargi 14448/88.

32 Zob. J. Zimmermann, op. cit., s. 312; W. Piątek, op. cit., s. 98; M. Grego-Hoffmann, Rola pełnomocnika $w$ postępowaniu sądowoadministracyjnym, Warszawa 2012, s. 58; a także np. wyrok TK z dnia 25 lutego 1992 r., K 4/91, OTK 1992 Nr 1, poz. 2; wyrok TK z dnia 10 stycznia 2005 r., K 31/03, OTK-A 2005 Nr 1, poz. 1.

${ }^{33}$ Wyrok TK z dnia 7 stycznia 1992 r., K 8/91, OTK $1992 \mathrm{Nr}$ 1, poz. 5; J. Jagoda, Sądowa ochrona samodzielności jednostek samorządu terytorialnego, Warszawa 2011, 128-129. 
pytania, czy prawo do sądu przysługuje również w sprawach administracyjnych?

Wykładnia językowa art. 6 ust. 1 Konwencji prowadzi do wniosku, że prawo do rozpatrzenia sprawy przed sądem dotyczy tylko spraw cywilnych lub karnych. Stoi to jednak w całkiem wyraźniej opozycji do treści preambuły Konwencji, w której rządy państw sygnatariuszy odwołują się do wspólnego dziedzictwa ideałów i tradycji politycznych, poszanowania wolności oraz rządów prawa. Nie wdając się w głębszą analizę zasady praworządności, wystarczy wspomnieć, że w ujęciu formalnym jednym $z$ warunków jej realizacji jest stworzenie w ramach organizacji państwowej instytucji i procedur umożliwiających kontrolę legalności aktów administracji publicznej przez niezawisły organ sądowy ${ }^{34}$. Można zatem stwierdzić, że w art. 6 Konwencji doszło do nieuzasadnionego ograniczenia treści zasady prawa do sądu jedynie do wskazanej w tym przepisie kategorii spraw cywilnych i karnych.

Taki stan rzeczy został poddany krytycznej ocenie Europejskiego Trybunału Praw Człowieka. W drodze wykładni operatywnej ustalono, że „w demokratycznym społeczeństwie [...] prawo do rzetelnego procesu sądowego zajmuje tak ważne miejsce, że jakakolwiek wykładnia zawężająca art. 6 nie odpowiadałaby ani celowi, ani charakterowi tego artykułu”35. Tym samym "prawo do sądu” abstrahuje do nadanego mu literą Konwencji znaczenia, a przepis art. 6 powinien znajdować zastosowanie również poza postępowaniem cywilnym czy karnym. Jak z powyższego wynika, ustalając zakres przedmiotowy art. 6 ust. 1 Konwencji można, a nawet należy stosować wykładnię rozszerzającą ${ }^{36}$ i objąć ją również sprawy administracyjne.

${ }^{34}$ Więcej na temat zasady praworządności patrz L. Morawski, Wstęp do prawoznawstwa, Toruń 1999, s. 237 i nst.

${ }^{35}$ Wyrok ETPC w sprawie Delcourt przeciwko Belgii z dnia 17 stycznia 1970 r., nr skargi 2689/65 (wszystkie orzeczenia ETPC powołane w tym rozdziale dostępne są w bazie orzeczeń Europejskiego Trybunału Praw Człowieka HUDOC pod adresem: hudoc.echr.coe.int/).

${ }^{36}$ Zob. M. A. Nowicki, Wokót Konwencji Europejskiej. Komentarz do Europejskiej Konwencji o Ochronie Praw Człowieka i Podstawowych Wolności, Warszawa 2013, s. 510-511. 
Podobne założenie stało się punktem wyjścia dla dalszych konstatacji Trybunału, który w licznych orzeczeniach ${ }^{37}$ dokonał wykładni, znajdującego się w treści w art. 6 ust 1. Konwencji, zwrotu „prawa i obowiązki o charakterze cywilnym”. Zastosowane zabiegi interpretacyjne pozwoliły nadać przedmiotowemu sformułowaniu niemal swoiste znaczenie, czyniąc $z$ niego koncepcję autonomiczną. Dostrzeżono bowiem, „że prawo traktowane jako publiczne w porządku prawnym jakiegoś państwa będzie uznane za prawo cywilne (prywatne) w rozumieniu art. 6 ust. 1 Konwencji lub odwrotnie”38. Doprowadziło to do stwierdzenia, że pojęcie „prawa i obowiązki o charakterze cywilnym" nie może być interpretowane wyłącznie w odniesieniu do prawa krajowego państw - stron Konwencji. W rezultacie ustalono, że przepis art. 6 ust. 1 Konwencji ma zastosowanie bez względu na status stron, rodzaj organu, który sprawuje jurysdykcję w sprawie oraz (co warte w tym miejscu szczególnego podkreślenia) bez względu na naturę przepisów, które wskazują, jak spór powinien być rozstrzygnięty ${ }^{39}$. Mogą być to zatem zarówno przepisy prawa cywilnego, karnego czy administracyjnego $^{40}$. Trybunał uznał przy tym, że art. 6 ust. 1 Konwencji znajduje zastosowanie w tych sprawach, których „wynik ma znaczenie dla szeroko rozumianych majątkowych uprawnień jed-

${ }^{37}$ Patrz np. wyroki ETPC w sprawach: Ringeisen przeciwko Austrii z dnia 16 lipca 1971 r., nr skargi 2614/65; Baraona przeciwko Portugalii $z$ dnia 8 lipca 1987, nr skargi 10092/82; Deumeland przeciwko Niemcom z dnia 29 maja 1986 r., nr skargi 9384/81; Lithgow i inni przeciwko Zjednoczonemu Królestwu z dnia 8 lipca 1986 r., nr skargi 9405/81; Rolf Gustafson przeciwko Szwecji z dnia 1 lipca 1997 r.; nr skargi 23196/94; J. S. i A. S. przeciwko Polsce z dnia 24 maja 2005 r., nr skargi 40732/98.

38 Wyrok ETPC z dnia 26 marca 1992 r. w sprawie Editions Périscope v. Francja, nr skargi 11760/85 loc. cit. § 35-40; Z. Kmieciak, op. cit., s. 98; M. A. Nowicki, op. cit., s. 514 .

39 Zob. wyrok w sprawie Georgiadis przeciwko Grecji z dnia 29 maja 1997 r., nr skargi 21522/93, loc. cit. § 34 .

${ }^{40}$ Więcej na ten temat patrz: A. Wróbel., Prawo do sądu, Warszawa 1999; M. Miłosz, Zagadnienie skargi indywidualnej do Europejskiego Trybunału Praw Człowieka jako środka zaskarżenia bezczynności organu administracji i przewlekłości postępowania administracyjnego, w: Bezczynność organu administracji publicznej $w$ postępowaniu administracyjnym, Warszawa 2011; W. Piątek, op. cit. 
nostki, niezależnie od tego, $\mathrm{z}$ jakiej gałęzi prawa się wywodzą"41. Dlatego pojęcie „sprawy cywilnej”, którym operuje się na gruncie Konwencji, pozostaje niedookreślone lub wręcz płynne ${ }^{42}$. Efekty prób doprecyzowania przedmiotowego pojęcia traktować należy tym samym jako tymczasowe. Obserwuje się bowiem proces obejmowania kognicją Europejskiego Trybunału Praw Człowieka kolejnych rodzajów spraw, które zaliczylibyśmy do kategorii spraw administracyjnych ${ }^{43}$.

Można zatem stwierdzić, że zagwarantowane w art. 6 ust. 1 Konwencji prawo do sądu przysługuje tak w sprawach cywilnych, karnych, jak i w sprawach administracyjnych ${ }^{44}$.

W treści art. 45 ust. 1 Konstytucji ustawodawca nie posłużył się żadnym określeniem, które pojęcie „sprawa” kojarzyłyby z konkretną gałęzią prawa ${ }^{45}$. Zabieg ten podyktowany był koniecznością nadania przedmiotowemu pojęciu szerszego kontekstu normatywnego. Rozpatrując relacje pomiędzy zakresem prawa do sądu w obu powyższych ujęciach (Konwencji i Konstytucji), wskazu-

${ }^{41}$ M. Krzyżanowska-Mierzewska, Dysfunkcje administracji publicznej $w$ Polsce w orzeczeniach Europejskiego Trybunału Praw Człowieka, w: Europeizacja administracji publicznej. Zbiór studiów, red. I. Lipowicz Warszawa 2008, s. 137. Jednocześnie zastrzeżono, że jeśli nawet przy wykładni komentowanego przepisu należy kierować się zasadami demokratycznego państwa prawa, to nie można czynić tego tak jakby przymiotnik „cywilny” w jego treści nie występował (Zob. wyrok ETPC w sprawie König przeciwko Niemcom z dnia 28 czerwca 1978 r., nr skargi 6232/73, loc. cit. § 90 oraz wyrok ETPC z dnia 12 lipca 2001 r. w sprawie Ferrazzini przeciwko Włochom, nr skargi 44759/98, loc. cit. § 25-27; Z. Kmieciak, op. cit., s. 99; M. A. Nowicki, op. cit., s. 514).

42 Z. Kmieciak, op. cit., s. 97.

${ }^{43}$ J. Chlebny, Saqdowa kontrola administracji $w$ świetle rekomendacji Rady Europy, „Państwo i Prawo” 2005, z. 12, s. 33.

${ }^{44}$ Art. 6 ust. 1 Konwencji stosuje się także do spraw przed sądami administracyjnymi. Pojęcie „sądu”, o którym mowa w tym przepisie konwencji, odnosi się także do sądu administracyjnego. K. Sieniawska, P. Skonieczny, Pojęcie „sądu administracyjnego” w Europejskiej Konwencji o Ochronie praw Człowieka i Podstawowych Wolności, „Casus” 1999, nr 2, s. 17.

${ }^{45} \mathrm{~W}$ zabiegu tym manifestuje się zasada równości wobec prawa wyrażona w art. 32 ust. 1 Konstytucji. M. Piłaszewicz, Prawo do sądu a prawo pomocy przewidziane $w$ Prawie o postępowaniu przed sądami administracyjnymi, „Monitor Podatkowy" 2009, nr 3, s. 11. 
je się, że art. 45 ust. 1 Konstytucji RP jest przepisem stanowiącym gwarancję ochrony konwencyjnych, jak i konstytucyjnych praw oraz wolności przed wszelkimi ich naruszeniami. W związku z tym zakres przedmiotowy prawa do sądu w ujęciu konstytucyjnym jest szerszy od konwencyjnej treści tego uprawnienia ${ }^{46}$. Oznacza to, że pojęcie sprawy na gruncie Konstytucji RP wykracza poza desygnat ustalony dla tego terminu w prawie cywilnym, karnym lub administracyjnym. Wynika to $z$ ogólnych zasad wykładni, zgodnie $\mathrm{z}$ którymi normy konstytucyjne muszą być traktowane jako punkt odniesienia do oceny poszczególnych pojęć ustawowych, a nie odwrotnie ${ }^{47}$. Tym samym konstytucyjne prawo do sądu zyskuje niemal autonomiczny i generalny charakter, a także przysługuje w możliwie szerokim zakresie przedmiotowym. Obejmuje tak sprawy cywilne, karne, jak i administracyjne ${ }^{48}$. Co więcej, dotyczy również tych spraw, które nie są sprawami cywilnymi, karnymi lub administracyjnymi, ale pozostają $\mathrm{w}$ zakresie właściwości sądów powszechnych i są załatwiane w postępowaniu cywilnym ${ }^{49}$.

Nie ulega przy tym wątpliwości, że zakres prawa do sądu musi być wyznaczany poprzez odniesienie do podstawowej funkcji sądów, którą jest, stosownie do art. 175 ust. 1 Konstytucji RP, sprawowanie wymiaru sprawiedliwości. Do istoty wymiaru sprawie-

${ }^{46}$ Zob. A. Łazarska, op. cit., s. 70. Warto przy tym odnotować treść postanowienia NSA z dnia 6 czerwca 2008 r., I OSK 614/08, w którym podkreślono, że należy tak interpretować przepisy obowiązującego prawa, aby nie zamykać stronie możliwości dochodzenia swych praw na drodze sądowej, o czym stanowi art. 45 ust. 1 i art. 77 ust. 2 Konstytucji Rzeczypospolitej Polskiej oraz art. 6 Konwencji.

47 Zob. wyrok TK z dnia 27 maja 2008 r., SK 57/0, OTK 2008 Nr 4/A, poz. 63.

${ }^{48}$ A. Kabat, Prawo do sadu jako gwarancja ochrony praw człowieka $w$ sprawach administracyjnych, w: Podstawowe prawa jednostki $i$ ich sadowa ochrona, red. L. Wiśniewski, Warszawa 1997, s. 225; H. Pietrzykowski, Prawo do sądu (wybrane zagadnienia), „Przegląd Sądowy” 1999, nr 11-12, s. 7; M. GregoHoffmann, Rola petnomocnika, s. 60; wyrok NSA z dnia 20 sierpnia 2008 r., I FSK 981/07; postanowienie NSA z dnia 19 maja 2009 r., I FZ144/09; wyrok NSA z dnia 27 października 2011 r., I OSK 1880/10.

49 Zob. postanowienie SN z 19 grudnia 2003 r., III CK 319/03, OSNC 2005/2/31. 
dliwości należy rozstrzyganie sporów prawnych - sporów ze stosunków prawnych ${ }^{50}$. Prawo do sądu nie służy jednak do rozstrzygania sporów pomiędzy organami władzy publicznej ${ }^{51}$. Odnosi się przede wszystkim do sporów prawnych między osobami fizycznymi i prawnymi, nie mieszczą się natomiast $\mathrm{w}$ tym pojęciu spory, w których nie jest stroną co najmniej jeden podmiot prawa prywatnego, „dotyczy to w szczególności sporów wewnątrz aparatu państwowego, a więc m.in. spraw ze stosunków nadrzędności i podporządkowania między organami państwowymi oraz spraw podległości służbowej pomiędzy przełożonymi, a także podwładnymi w organach państwowych" 52 .

\section{Wnioski}

Z powyższego wynika, że w demokratycznym państwie prawa prawo do sądu przysługuje każdej osobie fizycznej, osobie prawnej i jednostce organizacyjnej nieposiadającej osobowości prawnej we wszystkich kategoriach spraw. Krajowa reforma pionu sądownictwa administracyjnego przyczyniła się do wzmocnienia gwarancji prawa do sądu w sprawach administracyjnych.

Rozpatrując podmiotową stronę prawa do sądu administracyjnego, a zatem kwestię legitymacji skargowej, należy dostrzec prze-

50 Zob. L. Garlicki, Polskie prawo konstytucyjne. Zarys wykładu, Warszawa 1998, s. 146.

${ }^{51}$ Zob. J. Jagoda, op. cit., s. 132 oraz wskazane tam: J. Trzciński, Podmiotowy zakres skargi konstytucyjnej, w: Konstytucja. Wybory. Parlament. Studia ofiarowane Zdzisławowi Jaroszowi, red. L. Garlicki, Warszawa 2000, s. 213; postanowienie TK z dnia 22 maja 2007 r., SK 70/05, OTK-A 2007 Nr 6, poz. 60; wyrok TK z dnia 29 października 2009 r., sygn. akt K 32/08, OTK Nr 9, poz. 139.

${ }^{52}$ Tę drugą kategorię spraw - tj. z zakresu podległości służbowej - należy jednak rozumieć stosunkowo wąsko, ponieważ szereg elementów, kształtujących sytuację prawną podmiotu znajdującego się w relacji podległości służbowej, podlega kognicji sądu, np. jeśli chodzi o: wynagrodzenie, prawa socjalne czy wreszcie roszczenia odszkodowawcze. Zob. wyroki TK z dnia 14 grudnia 1999 r., sygn. SK 14/98, OTK 1999 Nr 7, poz. 163; wyrok z dnia 10 maja 2000, K 21/99, OK $2000 \mathrm{Nr} 4$, poz. 109. 
pisy, które regulują zasady wnoszenia skargi do wojewódzkiego sądu administracyjnego. I tak przepis art. $50 \S 1$ p.p.s.a. wskazuje kategorie podmiotów uprawnionych do skutecznego wniesienia skargi ${ }^{53}$. Przede wszystkim jest to każdy, kto ma w tym interes prawny ${ }^{54}$. Oznacza to, że legitymację skargową ma ten podmiot, który potrafi powiązać reprezentowany przez siebie interes $z$ przepisem prawa ${ }^{55}$. Są to przede wszystkim przepisy prawa materialnego, ale również procesowego, jak i ustrojowego ${ }^{56}$. Przy tym podmiot wnoszący skargę może to uczynić tylko we „własnej sprawie administracyjnej” ${ }^{57}$. To prowadzi do wniosku, że skarga do sądu

${ }^{53}$ Należy odnotować, że posiadanie legitymacji skargowej nie jest koniecznym warunkiem uzyskania przymiotu strony w postępowaniu sądowoadministracyjnym. Zgodnie $z$ art. 32 p.p.s.a. stroną w postępowaniu w sprawie sądowoadministracyjnej jest skarżący, czyli podmiot, który wniósł skargę na działanie, bezczynność lub przewlekłe prowadzenie postępowania przez organ. Nie musi być to przy tym podmiot wymieniony w art. $50 \S 1$ i $§ 2$ p.p.s.a. Innymi słowy samo wniesienie skargi czyni $z$ wnoszącego ją podmiotu stronę postępowania sądowoadministracyjnego, nawet jeśli skarga jest w sposób oczywisty niedopuszczalna. M. Jaśkowska, M. Masternak, E. Ochendowski, op. cit., s. 85-86.

${ }^{54}$ Uprawnionym do wniesienia skargi jest również prokurator, Rzecznik Praw Obywatelskich, Rzecznik Praw Dziecka oraz organizacja społeczna w zakresie jej statutowej działalności, w sprawach dotyczących interesów prawnych innych osób, jeżeli brała udział w postępowaniu administracyjnym. Natomiast, na podstawie art. $50 \S 2$ p.p.s.a, uprawnionym do wniesienia skargi jest również inny podmiot, któremu ustawy przyznają prawo do wniesienia skargi.

${ }^{5}$ W. Jakimowicz, Publiczne prawo podmiotowe, Kraków 2002, s. 414.

56 Zob. A. Kabat, Komentarz do art. 50 p.p.s.a., w: B. Dauter, B. Gruszczyński, A. Kabat, M. Niezgódka-Medek, Prawo o postępowaniu przed sądami administracyjnymi. Komentarz, Warszawa 2013; B. Adamiak, J. Borkowski, Postępowanie administracyjne i sądowoadministracyjne, Warszawa 2007, s. $424-425$.

57 Zob. T. Woś, H. Knysiak-Molczyk, M. Romańska, op. cit., s. 123. Podobne stanowisko znajdziemy w postanowieniu Sądu Najwyższego, w którym stwierdzono, że „wynikające $z$ uregulowania art. 45 ust. 1 Konstytucji RP, prawo do sądu nie jest, łaską ustawodawcy lecz fundamentalnym uprawnieniem, którego ustawy nie mogą ograniczać, a jedynie wskazywać drogę jego realizacji. Nie można jednak tracić z pola widzenia tego, że prawo to powstaje, gdy istnieje „sprawa”, a więc gdy ochrona określonych interesów jest w ogóle możliwa w postępowaniu sądowym przed sądami powszechnymi bądź przed sądami administracyjnymi” - postanowienie SN z dnia 18 listopada 2008 r., II CSK 303/08. 
administracyjnego nie stanowi actio popularis i wymaga istnienia materialnej legitymacji po stronie podmiotu korzystającego $z$ tych uprawnień ${ }^{58}$.

Przedmiotem postępowania sądowoadministracyjnego są sprawy sądowoadministracyjne. Zakres tego pojęcia (sprawa administracyjna) został wyznaczony przez szereg regulacji wskazujących na zakres przedmiotowy postępowania sądowoadministracyjnego. $\mathrm{Na}$ poziomie konstytucyjnym przedmiot postępowania sądowoadministracyjnego został wskazany w treści przepisów art. 184 i art. 166 ust. 3 Konstytucji RP ${ }^{59}$. Zgodnie $z$ art. 184 Konstytucji Naczelny Sąd Administracyjny oraz inne sądy administracyjne sprawują, w zakresie określonym w ustawie, kontrolę działalności administracji publicznej. Kontrola ta obejmuje również orzekanie o zgodności $z$ ustawami uchwał organów samorządu terytorialnego i aktów normatywnych terenowych organów administracji rządowej. Sądy administracyjne rozstrzygają również spory kompetencyjne między organami samorządu terytorialnego i administracji rządowej (por. art. 166 ust. 3 Konstytucji).

Prawo o postępowaniu przed sądami administracyjnymi normuje postępowanie sądowe $\mathrm{w}$ sprawach $\mathrm{z}$ zakresu kontroli działalności administracji publicznej oraz w innych sprawach, do których jego przepisy stosuje się z mocy ustaw szczególnych (sprawy sądowoadministracyjne; art. 1 p.p.s.a.). Natomiast, zgodnie $z$ art. 1 $\S 1$ p.u.s.a., sądy administracyjne sprawują wymiar sprawiedliwości przez kontrolę działalności administracji publicznej oraz rozstrzyganie sporów kompetencyjnych i o właściwość między organami jednostek samorządu terytorialnego, samorządowymi kolegiami odwoławczymi, jak również między tymi organami a organami administracji rządowej ${ }^{60}$. Kontrola ta sprawowana jest pod wzglę-

58 Zob. J. Zimmermann, op. cit., s. 313.

59 Zob. M. Jaśkowska, Właściwość sądów administracyjnych (zagadnienia wybrane), w: Koncepcja systemu prawa administracyjnego. Materiały ze Zjazdu Katedr Prawa Administracyjnego i Postępowania Administracyjnego, Zakopane 24-27 września 2006 r., red. J. Zimmermann, Kraków 2007, s. 567-568.

${ }^{60}$ Zakres przedmiotowy kontroli sądowoadministracyjnej wyznaczają przepisy art. $3 \S 2$ i $\S 3$ p.p.s.a oraz art. 4 p.p.s.a. 
dem zgodności z prawem, jeżeli ustawy nie stanowią inaczej (art. 1 $\S 2$ p.u.s.a.) ${ }^{61}$.

Powyższe pozwala stwierdzić, że krajowa kontrola sądowoadministracyjna została ukształtowana zgodnie $\mathrm{z}$ systemem klauzuli generalnej, co do zasady wszystkie akty administracyjne poddane są kontroli sądów administracyjnych ${ }^{62}$. System ten został jednak połączonym $z$ negatywną klauzulą enumeracyjną; istnieje pewna grupa przypadków, w których kontrola sądowoadministracyjna została wyłączona ${ }^{63}$.

Przyjęte wraz z reformą postępowania sądowoadministracyjnego rozwiązania, mające na celu urzeczywistnienie prawa do sądu, odpowiadają wobec tego postulatom i założeniom wyrażonym w przepisach Konwencji i Konstytucji RP.

\title{
STRESZCZENIE
}

\author{
Prawo do sądu a reforma \\ postępowania sądowoadministracyjnego
}

Reforma pionu sądownictwa administracyjnego podyktowana była wieloma różnymi czynnikami. Normatywnym źródłem reformy była Konstytu-

\footnotetext{
${ }^{61}$ Jak wskazuje T. Woś, postanowienia art. 1 in fine p.p.s.a,, zgodnie $z$ którymi przepisy tej ustawy miałyby normować postępowanie sądów administracyjnych w sprawach przekazanych do właściwości tych sądów w drodze „ustaw szczególnych”, należy uznać za rozwiązanie wykraczające poza zakres wymiaru sprawiedliwości powierzony sądom administracyjnym na podstawie art. 184 Konstytucji RP i jako takie za niekonstytucyjne. T. Woś, H. Knysiak-Molczyk, M. Romańska, op. cit., s. 27.

${ }^{62} \mathrm{~W}$ związku z tak szeroko zakreślonym przedmiotem postępowania sądowoadministracyjnego wskazuje się, że nie ma jednego, jednolitego przedmiotu postępowania sądowoadministracyjnego i nie da się zbudować takiej konstrukcji sprawy sądowoadministracyjnej, która obejmowałaby wszystkie kategorie sporów prawnych mieszczących się w zakresie kontroli działalności administracji publicznej. T. Woś, H. Knysiak-Molczyk, M. Romańska, op. cit., s. 28; M. Wilbrandt-Gotowicz, Pojęcie sprawy sądowoadministracyjnej, w: Instytucja pytań prawnych $w$ sprawach sądowoadministracyjnych, Lex 2011.

${ }^{63}$ Sprawy objęte kognicją sądów administracyjnych ujęte zostały w art. 5 p.p.s.a.
} 
cja Rzeczypospolitej Polskiej z dnia 2 kwietnia 1997 r. Jednak, reformując procedurę sądowoadministracyjną ustawodawca realizował nie tylko konstytucyjne zasady i obowiązki, ale również urzeczywistniał postanowienia umów międzynarodowych, w tym Europejskiej Konwencji o Ochronie Praw Człowieka i Podstawowych Wolności oraz nawiązywał do rekomendacji Komitetu Rady Europy, tak, aby przyszła ustawa zapewniała przede wszystkim ochronę szeroko rozumianych praw człowieka. Wśród praw człowieka, ochronie których sprzyjać miała reforma sądowoadministracyjna, szczególne znaczenie przypisano konieczności zagwarantowania prawa do sądu. W demokratycznym państwie prawa prawo do sądu przysługuje każdej osobie fizycznej, osobie prawnej i jednostce organizacyjnej nieposiadającej osobowości prawnej we wszystkich kategoriach spraw. Przyjęte wraz $z$ reformą postępowania sądowoadministracyjnego rozwiązania, mające na celu urzeczywistnienie prawa do sądu, odpowiadają postulatom i założeniom wyrażonym w przepisach Konwencji i Konstytucji RP.

Słowa kluczowe: prawo do sądu; sąd administracyjny; postępowanie sądowoadministracyjne; reforma sądownictwa administracyjnego; Europejska Konwencja o Ochronie Praw Człowieka i Podstawowych Wolności; Konstytucja RP

\section{SUMMARY}

The right to a fair trial and the reform of the administrative court procedure

The reform of the administrative judiciary segment was influenced by various factors. The regulatory basis of the reform was the Constitution of the Republic of Poland of 2 April 1997. However, by reforming the administrative court procedure, the legislator was not only realizing constitutional rules and obligations but also realizing the provisions of international agreements, including but not limited to the Convention for the Protection of Human Rights and Fundamental Freedoms, and also referring to the recommendation of the Committee of Ministers of the Council of Europe so that the future act ensured, above all, the protection of broadly defined human rights. Out of human rights, the protection of which the reform was supposed to foster, the necessity of guaranteeing the right to a fair trial was of great importance. In a democratic legal state, every natural person, every legal entity and every organizational entity without legal 
personality has the right to a fair trial in all types of cases. The solutions, which were adopted together with the reform of the administrative court procedure and the goal of which was to make the right to a fair trial a reality, follow the stipulations and assumptions expressed in the Convention and in the Constitution of Poland.

Key words: right to a fair trial; administrative court; administrative court procedure; reform of the administrative judiciary; European Convention for the Protection of Human Rights and Fundamental Freedoms; Constitution of the Republic of Poland

\section{BIBLIOGRAFIA}

Adamiak B., Borkowski J., Postępowanie administracyjne i sądowoadministracyjne, Warszawa 2007.

Chlebny J., Saqdowa kontrola administracji $w$ świetle rekomendacji Rady Europy, „Państwo i Prawo” 2005, z. 12.

Czeszejko-Sochacki Z., Konstytucyjna zasada prawa do sądu, „Państwo i Prawo" 1992, z. 10.

Czeszejko-Sochacki Z., Prawo do sądu w świetle Konstytucji Rzeczypospolitej Polskiej (ogólna charakterystyka), „Państwo i Prawo” 1997, z. 11-12.

Dauter B., Gruszczyński B., Kabat A., Niezgódka-Medek M., Prawo o postępowaniu przed sądami administracyjnymi. Komentarz, Warszawa 2013.

Garlicki L., Polskie prawo konstytucyjne. Zarys wykładu, Warszawa 1998.

Garlicki L., Prawo do sądu, w: Prawa człowieka. Model prawny, red. R. Wieruszewski, Wrocław 1991.

Góra-Błaszczykowska A., „Rzetelne postępowanie przed sądem” według Trybunału Konstytucyjnego", w: Jus et Remedium. Księga jubileuszowa Profesora Mieczysława Sawczuka, red. A. Jakubecki, A. J. Strzępka, Warszawa 2010.

Grego-Hoffmann M., Rola pełnomocnika $w$ postępowaniu sądowoadministracyjnym, Warszawa 2012.

Hauser R., Prawo do sądu - referat, w: Konferencja naukowa: Konstytucja $R P w$ praktyce, Warszawa 1999.

Jagoda J., Sądowa ochrona samodzielności jednostek samorządu terytorialnego, Warszawa 2011.

Jakimowicz W., Publiczne prawo podmiotowe, Kraków 2002.

Jaśkowska M., Masternak M., Ochendowski E., Postępowanie sądowoadministracyjne, Warszawa 2005.

Jaśkowska M., Właściwość sądów administracyjnych (zagadnienia wybrane), w: Koncepcja systemu prawa administracyjnego. Materiały ze 
Zjazdu Katedr Prawa Administracyjnego i Postępowania Administracyjnego, Zakopane 24-27 września 2006 r., red. J. Zimmermann, Kraków 2007.

Kabat A., Prawo do sądu jako gwarancja ochrony praw człowieka $w$ sprawach administracyjnych, w: Podstawowe prawa jednostki $i$ ich sadowa ochrona, red. L. Wiśniewski, Warszawa 1997.

Kędzia Z., Prawa, wolności i obowiązki człowieka i obywatela w nowej polskiej Konstytucji, Poznań 1990.

Kmieciak Z., Postępowanie administracyjne i sądowoadministracyjne a prawo europejskie, Warszawa 2010.

Kowalik-Bańczyk K., Prawo do obrony w unijnych postępowaniach antymonopolowych $w$ kierunku unifikacji standardów proceduralnych $w$ Unii Europejskiej, Warszawa 2012.

Krzyżanowska-Mierzewska M., Dysfunkcje administracji publicznej $w$ Polsce $w$ orzeczeniach Europejskiego Trybunału Praw Człowieka, w: Europeizacja administracji publicznej. Zbiór studiów, red. I. Lipowicz, Warszawa 2008.Łazarska A., Rzetelny proces cywilny, Warszawa 2012.

Mądrzak H., Prawo do sądu jako gwarancja ochrony praw człowieka, w: Podstawowe prawa jednostki $i$ ich sądowa ochrona, red. L. Wiśniewski, Warszawa 1997.

Michalska A., Prawa człowieka $w$ systemie norm międzynarodowych, Warszawa-Poznań 1982.

Miłosz M., Bezczynność organu administracji publicznej $w$ postępowaniu administracyjnym, Warszawa 2011.

Nowicki M. A., Wokót Konwencji Europejskiej. Komentarz do Europejskiej Konwencji o Ochronie Praw Człowieka i Podstawowych Wolności, Warszawa 2013.

Ochendowski E., Postępowanie administracyjne ogólne, egzekucyjne i sądowoadministracyjne, Torun 2012.

Piątek W., Podstawy skargi kasacyjnej $w$ postępowaniu sądowoadministracyjnym, Wolters Kluwer 2011.

Pietrzykowski H., Prawo do sądu (wybrane zagadnienia), „Przegląd Sądowy" 1999, nr 11-12.

Pogonowski P., Realizacja prawa do sądu w postępowaniu cywilnym, Warszawa 2005.

Sieniawska M., Skonieczny P., Pojęcie „sadu administracyjnego” $w$ Europejskiej Konwencji o Ochronie praw Człowieka i Podstawowych Wolności, „Casus” 1999, nr 2.

Trzciński J., Podmiotowy zakres skargi konstytucyjnej, w: Konstytucja. Wybory. Parlament. Studia ofiarowane Zdzistawowi Jaroszowi, red. L. Garlicki, Warszawa 2000. 
Tuleja P., Prawo sędziowskie z perspektywy konstytucyjnej, w: Konstytucja i sadowe gwarancje jej ochrony. Księga jubileuszowa Profesora PawŁa Sarneckiego, red. K. Świerk-Bożek, Kraków 2004.

Wasilewski A., Sadowa kontrola administracji a problem prawa do sadu, w: Księga pamiątkowa prof. E. Ochendowskiego, Toruń 1999.

Wędrychowski M. P., Prawo do „uczciwej rozprawy” w Europejskiej Konwencji Praw Człowieka, „Przegląd Sądowy” 1991, nr 5-6.

Wilbrandt-Gotowicz M. B., Instytucja pytań prawnych $w$ sprawach sadowoadministracyjnych, Warszawa 2011.

Wilbrandt-Gotowicz M. B., Skarga kasacyjna $w$ postępowaniu sądowoadministracyjnym, Toruń 2005.

Wiśniewski L., Podstawowe prawa jednostki $i$ ich sądowa ochrona, Warszawa 1997.

Woś T., Condiciones necessariae dwuinstancyjnego sądownictwa administracyjnego, w: Dziedzictwo prawne XX wieku. Księga pamiątkowa z okazji 150-lecia TBSP UJ, Kraków 2001.

Woś T., Knysiak-Molczyk H., Romańska M., Postępowanie sądowoadministracyjne, Warszawa 2004.

Woś T., Reforma sądownictwa administracyjnego - projekty dalekie od ide$a ł u$, „Państwo i Prawo” 2001, nr 7.

Wróbel A., Prawo do sądu - tezy referatu, w: Konstytucja RP w praktyce. Konferencja naukowa, Warszawa 1999.

Zieliński A., Postępowanie przed NSA $w$ świetle „prawa do sprawiedliwego procesu sądowego”, „Państwo i Prawo” 1992, z. 7.

Zieliński A., Prawo do sądu i organizacja władzy sądowniczej, w: Księga XX-lecia Orzecznictwa Trybunału Konstytucyjnego, red. M. Zubik, Warszawa 2006.

Zimmermann J., Prawo do sadu $w$ prawie administracyjnym, „Ruch Prawniczy Ekonomiczny i Socjologiczny" 2006, zeszyt 2.

Zubik M., Sprawowanie wymiaru sprawiedliwości $w$ świetle Konstytucji i orzecznictwa Trybunału Konstytucyjnego, „Przegląd Sejmowy” 2005, nr 3. 